\title{
The application of authentic assessment in history learning at Don Bosco high school Padang
}

\author{
Ari P Silalahi \\ Padang , Indonesia, Padang - Indondesia, (arisilalahi809@gmail.com)
}

\begin{abstract}
This study aims to describe how teachers in applying authentic assessment in historical learning in accordance with the demands of Curriculum 2013. This research is a qualitative descriptive study. The data collection techniques used are observation, interview, and documentation study. Data were analyzed by data reduction, data presentation, and conclusions. The result of the research shows that: 1) teachers and principals are able to apply authentic assessment in history lessons based on attitude, knowledge, and skill attitudes assessment, 2) real authentic assessment implemented by teacher in the field so that the result of the learner achievement until end of semester) 3) the assessment done by the teacher is not just knowledge but how the teacher understands each developmental characteristics of the learners, 4) by performing an authentic assessment in the learning history of learners have the intellectual ability and academic brilliance, the heirs of the values of nationality and have concern for the problems of life society and nation by conducting an authentic assessment in the learning history of learners having intellectual ability and academic brilliance, the heirs of national values and having concern for the present and future life of society.
\end{abstract}

Keywords: authentic assessment, historical learning outcomes

\section{Introduction}

One of the important elements of the changing of Curriculum 2013 requirement is Assessment Standard. Assessment in the 2013 curriculum refers to Permendikbud Number 23 of 2013 on Education Appraisal Standards. One of the reasons for the change in assessment standards applied in the Curriculum 2013 is that in the life of Indonesian society there has been a lot of moral decadence. Educational experts worry us as a nation is heading for destruction with characterized attitudes and behaviors that tend to be immoral and lack respect for human values. On the other hand learners have not got the internalization of values maturely and meaningfully. This is because in the process of teaching and learning is still too focused on the cognitive aspect only so that affective and psychomotor aspects that are characterized less attention. While it is time in the learning process has been balancing between high academic mastery with spiritual-based character emphasis. The combination of these two things can be a provision in the face of global challenges.

Assessment in the Curriculum 2013 using authentic assessment is actually contained in Education Unit Level Curriculum, but in the field implementation has not run optimally. For that reason, in the Curriculum 2013 this authentic assessment becomes a serious emphasis where teachers in carrying 
out assessment of learners' outcomes really pay attention to authentic assessment. In an authentic assessment the teacher should conduct assessments not only on the basis of Basic Competence, but also on Core Competencies and Graduate Competency Standards. This assessment standard aims to ensure: (1) planning the assessment of learners in accordance with the competencies to be achieved and based on the principles of assessment, (2) the implementation of professional judgment, open, educative, effective, efficient and appropriate to the socio-cultural context, (3) reporting the results of the evaluation of learners objectively, accountable, and informative.

Don Bosco high school is the first private school to be included in the reference school for the implementation of the 2013 curriculum in the city of Padang. As explained the selection of schools is based as a reference for the implementation of the Curriculum 2013 as it meets the Minimum Service Standards of National Education. At the beginning of the implementation of Curriculum 2013 at this school teachers are still difficult to understand every change every 2013 Curriculum standard plus the increasing burden of teachers in completing the learning process tools to support the outcome of the assessment of learners. Historical subjects that incidentally is a subject matter that is considered by students as a very boring lesson becomes a challenge for history teachers in Don Bosco high school to be a material that interests learners in Curriculum 2013. During this assessment on the subject of history still emphasizes the cognitive aspect but after the implementation of the 2013 curriculum, the assessment is emphasized on three aspects of competence. Based on interviews with High School Principal Don Bosco Padang note that the assessment in Curriculum 2013 so much, so it takes a long time. Each teacher teaches, must prepare the assessment formats, in the attitude assessment just for example there are still many formats filled, the assessment of knowledge there are other formats and skills and even all subjects must perform authentic assessments such as existing formats.

In addition, based on the results of interviews with the Senior High School Curriculum Don Bosco Padang obtained information that authentic assessment is very good applied in school because it helps teachers in obtaining information about the development characteristics of learners both in the sphere of attitude, knowledge, and skills.

Likewise, the history teacher in the school is known that the 2013 Curriculum assessment was initially greeted positively and enthusiastically, but after deepening the contents of the 2013 curriculum, especially the assessment of learning outcomes is too complicated to implement and will incriminate teachers because of the increasing number of judgments. Teachers increasingly burdened with many tasks, because of the many assessments of the students are also affected by the impact of the students are also charged with the job so many tasks because teachers must fill in the format of so many assessments, in addition teachers are still difficult in carrying out authentic assessment by the procedures correct. But with the ongoing training, teachers become accustomed to carry out assessment in 3 aspects of competence, especially in history subjects. With an authentic assessment the teacher can measure students 'ability and find out whether the student is really learning or not, whether the student learning experience has a positive influence on students' development, both intellectual and mental students. This is because the result of an authentic assessment will determine what treatment the teacher should give students. Teachers can implement follow-up program with reference to the achievement of student competence.

In the Curriculum 2013 the subject of history also gets an important position where in the Curriculum 2013 the subject of history is divided into two, namely compulsory history and history of interest so that the history teacher gets a lot of opportunity in exploring history. This is so that learners are always aware and learn the history of the nation, and not just memorize events and figures of the year, but rather stimulate learners to sharpen their analysis and critical attitude in understanding the past useful in the future, then learners can embed his awareness to be conscious and willing to learn the history of his nation's past, to embrace a sense of nationalism and not always lead to science and pursue economic advantage. It is a challenge for teachers to teach history subjects 
in Curriculum 2013, where teachers not only give material but how teachers instill characters based on historical values so that the outcomes of learners will become learners who have the competence of attitude, knowledge and skills in understand history

Hence, the subject of history based on the 2013 curriculum becomes a challenge for teachers, where the history teacher will also teach twice as much as other lessons because history lessons are an option at all grade levels. Teachers should be able to apply authentic assessments to all learners in order to see educated outcomes as learners of character and respect for national values.

Several related researches and relevance to this research include a journal written by Research conducted by Ihwan Azis (2012) entitled Evaluation of Implementation of Economic Learning Evaluation Based on Permendiknas Number 20 Year 2007 in Senior High School of Klaten Regency. The results showed that the teacher's understanding of the concept of assessment entered in the high category of $(89.1 \%)$ or as many as 41 teachers. Understanding of the technique of entry into the high category of $70 \%$ or as many as 32 teachers. Understanding of teacher assessment activities included in the high category of $100 \%$ or as many as 46 teachers.

Furthermore, research Ade Cintya Putri (2015) State University of Yogyakarta, mentioned in the written thesis that the implementation of authentic assessment in Thematic Learning on Students Class IV A School Elementary School 4 Wates Kulon Progo Regency. This study aims to describe the knowledge of teachers and principals as well as the implementation of authentic assessment in thematic learning in fourth grade students A SD Negeri 4 Wates, Wates District, Kulon District. The results show that: 1) teachers and principals know about authentic assessment in thematic learning, 2) teachers carry out authentic assessment in thematic learning that includes attitude, knowledge, and skill competency assessment. Assessment of attitude competencies is conducted through observation techniques, self-assessment, peer assessment, and journal assessment. The assessment of knowledge competence is carried out through written test techniques, oral tests, and assignments. Skill competency assessment is conducted through performance assessment techniques, project valuation, product assessment, and portfolio assessment. Research conducted by Fitriana Anjas Asmara (2014), entitled Implementation of Authentic Assessment on High School Biology Subjects Applying KTSP and Curriculum 2013. The results show that most of the biology teachers who teach with KTSP and Curriculum 2013 have perceptions of understanding authentic assessment and its aspects. Overall, authentic assessments have been implemented by biology teachers according to the Education Assessment Standards, although their implementation is not yet optimal. Most aspects of authentic assessment are almost always implemented by biology teachers. Understanding and implementing aspects of authentic assessment vary, depending on the type of assessment technique.

\section{Method}

The type of this research is qualitative research. This research was conducted at Don Bosco High School in Padang for one semester. Criteria for determining informants in this study is the subject is the subject of history teacher Don Bosco SMA Padang. In order to obtain the required data, done through three ways of interview, observation, documentation. Observations, interviews and documentation were conducted in two stages: (1) grand tour stage that is observation in general and broad, (2) mini tour stage that is observation focused and narrowed. To examine the validity of the data in this study is done by: 1) extension of participation, 2) more diligent observation, and 3) triangulation of data then perform data analysis in this research conducted by performing steps as proposed Miles and Huberman namely: reducing data, display data, and conclude.

\section{Results and Discussion}

Don Bosco high school located on Jalan Khairil Anwar no.8, Padang is the oldest private school in the province of West Sumatra. In terms of Don Bosco high school location is very strategic, in addition 
to being in the city center, this school is also adjacent to the structure of historic buildings, such as old buildings of the Dutch relics. Given the status has been equated then this school is for the general public. Don Bosco Senior High School has a distinctive characteristic in which learners consist of diverse ethnic and religious backgrounds, as well as their teachers. Although there are many differences in Don Bosco high school but tolerance is highly regarded in this school. The attitude of mutual respect and appreciation of differences among learners is always instilled by the teachers as one of the character formers of learners. Then, with complete facilities and infrastructure in schools will be able to support the implementation of the Curriculum 2013, especially the implementation of the assessment.

The condition of these underprivileged students is given a scholarship by the school to help ease the burden on the parents of learners. In addition to scholarships for underprivileged students, scholarships are also provided for students who excel at both provincial and national levels. So, the school's attention to learners is huge because it is the vision and mission of Don Bosco high school . For achievement, high school students Don Bosco very much carve the achievement of both academic and non academic. Based on the results of interviews with high school oscilloscope coach Don Bosco high school that the concern of high school Don Bosco high school to increase the achievement of high school Don Bosco students is very high. Schools give appreciation and time to learners to develop their talents and interests.

Beginning of the Curriculum 2013 teachers in Don Bosco high school still difficult to apply directly in the field, especially the curriculum assessment system 2013 which is so filled by every subject teacher. In contrast to the previous curriculum more assessments look at the cognitive aspects, but in the Curriculum 2013 this assessment of the teacher should look the affective, cognitive and psychomotor aspects of each learner. Don Bosco high school average every subject teachers rate almost 300 students per week. So here the teacher should really know the various characteristics of learners. Not only the difficulties in the Curriculum 2103 assessment system, teachers are also faced with the changes of the lesson plans in the Curriculum 2013. The lesson plans compiled by teachers based on a government-defined syllabus is arranged in such a way as to be done in the field and the facts obtained in the field will determine the assessment of learners. Furthermore, in the Curriculum 2013 the subjects of history are divided into two groups, namely the compulsory group and the specialization group, the teachers in each group of lessons are also attempted differently so as not to overload the making of learning tools and teacher focus to perform its function as an educator. As implemented in Don Bosco Senior High School, the subject history teacher at Don Bosco high school teaches cross-subjects to facilitate teachers in implementing the Curriculum 2013.

Learning history in the previous curriculum is different from the history lesson in the Curriculum 2013 based on competence and character. During this learning history in school is considered as a lesson that is considered a very tedious lesson learners and berkutat much on theory and memorization. This does not mean that history lessons are not interesting but there are certain factors that cause them to happen. The 2013 curriculum changes are born to improve the education system, hence the subjects of history at high school level.

Based on the results of field research, found the initial process of applying authentic assessment in high school Don Bosco Padang is preparing learning tools. One of the results of the National Curriculum Bimtek hence since the new school year the completeness of the device that must be owned by the teacher is the existence of Teacher Workbook. The completeness of the teacher workbook is aware of the observations of researchers in Don Bosco high school all documents of the teacher workbook for all subject teachers is very complete. In the realm of authentic assessment in history subjects then the teacher conduct attitude assessment. The affective assessment (attitude) in learning history of interest in Don Bosco high school based on competency-based curriculum that is Core Competence which become spiritual, social, knowledge and skills). The four groups become the 
reference of Basic Competence and should be developed in each learning event in an integrative manner. Based on research results at Don Bosco high school that attitude assessment is done by all subject teachers along with Guidance and Counseling teachers and homeroom. Assessment of this attitude is very important to see the character development of learners. The result of attitude assessment during the one semester period at Don Bosco high school gis reported in the form of a very good predicate, good, sufficient, or lacking as well as a description that describes the behavior of learners. As a basic assessment of attitudes in this school is based on rules of discipline that apply in high school Don Bosco high school. The way in which the teacher performs an affective assessment is by observation. Observation is an assessment conducted by the subject history teacher specializing in learning history of specialization in class and out of class. Here the teachers of history subjects make very detailed observations of each learner. Besides the observation of teachers also do self-assessment is the assessment conducted by learners to assess the advantages and disadvantages of the learners themselves. After doing self-assessment then learners also do assessment anthonsicipate students that ask learners to judge each other. Furthermore, the journals 'assessment is made of educators' records of learners inside and outside the classroom containing information on observations of the behavior and attitudes of learners. Based on observations and documentation it was found that journal valuation was done by the homeroom made in the form of the learner's records. The records contain the weakness or lack of learners to be a document for the homeroom who will be carried out coaching and guidance by homeroom teachers and Counseling Guidance.

After the teacher perform an affective assessment then followed by doing a cognitive assessment is the assessment conducted by teachers to measure the level of achievement or mastery of learners of the subject matter. The interview result shows that the cognitive assessment conducted by the history teacher of Don Bosco High School in Padang consisted of daily replication assessment conducted three times in one semester with remedial, one mid semester without any remedial, then there was the assignment and the final repetition of semester. Then the teacher perform psychomotor assessment is the assessment done by the teacher by looking at the ability to act someone after receiving a certain learning experience. psychomotor is associated with learning outcomes through its skill as a result of the achievement of knowledge competence. This implies the competence of the skills of the implications of achieving the competence of learners' knowledge. Psychomotor assessment is done by students inside and outside the classroom. Psychomotor assessment during one semester consists of psychomotor assessment in daily test, mid-term repetition, and repetition at the end of semester.

After the assessment, the whole process is processed by the teacher at the end of the semester. From the process will get the result that learners who achieve mastery and learners who have not reached mastery. Students will be given a follow-up program that is remedial and enrichment program. Enrichment program is a program conducted by teachers to learners who have achieved completeness in learning. Remedial program is intended for learners who have not achieved minimal value in certain basic competence while the enrichment program is the deepening and extension of the competencies studied. Enrichment is usually given after the learners are known to have reached the minimal mastery criteria based on the results of each repetition.

\section{Conclusions}

Based on the results of research and discussion that one of the reasons for changes in assessment standards in the Curriculum 2013 is not yet using competency-based assessment standards, on the other hand learners have not got the internalization of values mature and meaningful. This is because in the process of teaching and learning is still too heavily on the cognitive aspect so that affective and psychomotor aspects that have less character attention. So to strengthen the character of learners, the subjects of history get an important position in the Curriculum 2013 where the history teacher gets a 
lot of opportunities in exploring history. This is so that learners are always aware and learn the history of the nation, and not just memorize events and figures only year, but stimulate learners to sharpen their analysis and critical attitude in understanding the useful future of the future. To reinforce it then the assessment in the history of learning is carried out authentically means that the assessment is really implemented in real to the learners that includes three competencies namely attitude competence, knowledge and skills. The three assessment competencies are developed by taking into account the characteristics of each learner, so that the school produces graduates of learners who already have three competencies in facing challenges in the future.

\section{References}

Majid,A .(2014). Implementation of Curriculum 2013. Bandung: Interes

Mulyasa, E.(2013). Development and Implementation of Curriculum 2013. Bandung: Remaja Rosdakarya

Kunandar. (2013). Authentic Assessment (Assessment of Learning Outcomes Learners Based on Curriculum 2013. Bandung: Remaja Rosdakarya

Hamalik, Oemar.(2010). Curriculum Development Management. Bandung: Remaja Rosdakarya.

Hasan,Hamid. (1998). Policy and Implementation of History within the Ministry of Education and Culture. Jakarta : Depdikbud

Iryasman. Integrating the Values of Character, Literacy, 21st Century Skill and HOTS in Learning at the National Seminar STKIP PGRI Sumatera Barat.

Kurinasih. (2014). Implementation of the 2013 Curriculum: Concepts and Implementation. Surabaya: Kata Pena. 